\title{
Structural and functional responses of Carex aquatilis to increasing sodium concentrations
}

\author{
Dale H. Vitt • Lilyan C. Glaeser $\cdot$ Melissa House $\cdot$ Samantha P. Kitchen
}

Received: 3 April 2020/Revised: 3 August 2020/Accepted: 18 August 2020/Published online: 1 September 2020

(C) The Author(s) 2020

\begin{abstract}
Carex aquatilis is a widespread boreal species that is abundant in open fens and marshes. The species has broad natural tolerances to differing water levels and ion concentrations including occurrences in brackish marshes but not sodic wetlands. Sandhill Wetland, constructed on Syncrude Canada Ltd. mineral surface lease in the Athabasca Oil Sands Region, is a research site that was engineered to support a selfsustaining wetland. The site is currently in its eighth year post wet-up and is partially dominated by $C$. aquatilis. Increasing $\mathrm{Na}^{+}$concentrations in the porewaters at Sandhill Wetland are an on-going concern for the performance of the existing plant communities. Here we examine the responses of $C$. aquatilis to an increasing regime of sodium carried out in a greenhouse experiment. We posed three questions for this experiment: (1) is there a threshold response for performance of $C$. aquatilis to increasing sodium, (2) if so, does it occur in the range of sodium that is present at current reclamation programs, and (3) is $C$. aquatilis resistant to high concentrations of sodium? Carex aquatilis survived all treatment concentrations
\end{abstract}

Electronic supplementary material The online version of this article (doi:https://doi.org/10.1007/s11273-020-09746-9) contains supplementary material, which is available to authorized users.

D. H. Vitt $(\bowtie) \cdot$ L. C. Glaeser · M. House · S. P. Kitchen School of Biological Sciences, Southern Illinois University, Carbondale, IL 62901, USA

e-mail: dvitt@siu.edu of sodium including the highest treatment of $2354 \mathrm{mg}$ $\mathrm{L}^{-1}$. In general, both structural and functional attributes of $C$. aquatilis did not differ between the 17 and $1079 \mathrm{mg} \mathrm{L}^{-1}$ treatments; however, performances of all attributes were reduced in the $2354 \mathrm{mg}$ $\mathrm{L}^{-1}$ treatment. Belowground biomass had greater decreases compared to aboveground components, including both biomass and photosynthesis. The aboveground decreases in performance were associated with exclusion of sodium from the aboveground components by the belowground components. Reduction in photosynthesis was strongly correlated with reduced stomatal conductance and lower transpiration. Although $C$. aquatilis demonstrated a wide tolerance to sodium concentrations, a clear threshold was present between 1079 and $2354 \mathrm{mg} \mathrm{L}^{-1}$. These decreases in performance in our greenhouse trials were at levels currently present at Sandhill Wetland, and careful assessment of sodium concentrations in the near future needs to be continued.

Keywords Alberta - Boreal · Carex aquatilis · Oil sands reclamation - Salinity trial $\cdot$ Sandhill $\cdot$ Wetland . Sodium $\cdot$ Wetland

\section{Introduction}

Water sedge (Carex aquatilis Wahlenb., Cyperaceae) has a circumboreal distribution with extensions 
southward in the Western Cordillera of North America and the Kamchatka Peninsula, and is abundant in boreal peatlands (Hultén 1968; Gignac et al. 2004). It has a wide range of tolerance for $\mathrm{pH}(3.0-8.5)$, electrical conductivity $\left(0-8820 \mu \mathrm{S} \mathrm{cm}^{-1}\right)$ and $\mathrm{Ca}^{+2}$ concentrations $\left(0.2-146.6 \mathrm{mg} \mathrm{L}^{-1}\right)$ and is common in all fen types as well as some marshes and shallow open waters (Koropchak et al. 2012). The species is also highly tolerant of differing water levels and can be abundant at levels between -80 and $+36 \mathrm{~cm}$ from the soil surface (Koropchak et al. 2012). Carex aquatilis occurs in brackish marshes (Hartsock 2020) and may be a dominant species in reclaimed mine pits (Purdy et al. 2005), often colonizing disturbed areas (Bliss and Grulke 1988). The species also occurs on wet sandy or clay soils (Chapin and Chapin 1981) and is one of the first colonizers of disturbed roadsides on both organic and mineral soils. Carex aquatilis is an aggressive colonizer producing rhizomatous shoots twice a year (Bernard and Gorham 1978), with flowering in May to June and seed maturity in August to September (Gorham and Somers 1973). Seeds are abundant and readily germinate (Koropchak et al. 2012). These attributes make C. aquatilis a candidate as an effective species for establishing wetland plant communities on post-mined substrates (Vitt et al. 2011); however, few data describing limitations to survival from extreme $\mathrm{pH}$, salinity, and $\mathrm{Na}^{+}$concentrations are available.

The impact of tailings water oil sands processing has been studied for a number of upland species (Renault et al. 1998; Khasa et al. 2002) with species exposed to high sodicity having difficulty maintaining turgor pressure, appearing stressed, and with morphological changes. Wetland species have also been subjected to increasing sodium concentrations with reduced growth and eventual death at highest concentrations (Koropchak and Vitt 2013-Typha latifolia and Glaeser et al. 2016-Beckmannia syzigachne). Choo et al. 2001 examined $\mathrm{Na}^{+}$tolerance using European species of Carex; however, no studies have quantified $\mathrm{Na}^{+}$tolerance in any North American species (Montemayor et al. 2008).

Wetlands are dominant landscape features across the Athabasca Oil Sands Region (AOSR) of Alberta, Canada occupying approximately $62 \%$ of the area (Raine et al. 2002; Rooney et al. 2012), with fens covering $21-53 \%$ of the Oil Sands Area (Wieder et al. 2016). As a consequence of intensive oil sands mining activities, approximately $800 \mathrm{~km}^{2}$ of boreal forest and wetlands have been disturbed in some capacity across the region (Government of Alberta 2015). Because many future wetland reclamation sites will be constructed above previously mined open-pits that contain high salinity or sodic substrates (Kessler et al. 2010; Vessey et al. 2019), managing for potential salt intrusion is a major concern. Salinity management is particularly important for future wetland reclamations because most wetland plants exhibit low tolerances to saline conditions (Renault et al. 1999; Mollard et al. 2012; Glaeser et al. 2016). Wetlands with high concentrations of sodium, although rare, do occur in northern Alberta and may provide good proxies for a reclaimed landscape; however, they have a unique flora that eliminates many common species (Purdy et al. 2005; Trites and Bayley 2009; Raab and Bayley 2013).

Oil sands open pit mining creates large areas of extreme and novel environmental conditions. Especially concerning are potentially high concentrations of $\mathrm{Na}^{+}$in the substrate of the reclaimed sites. Regional deep ground water that is high in $\mathrm{Na}^{+}$(Adams et al. 2004) as well as the process of extracting oil from the intact oil sand result in post-mining landscapes with high $\mathrm{Na}^{+}$(Renault et al. 1998). Returning a portion of the mined areas to wetlands with some similarity to those present before mining is a significant challenge. Among the key ingredients for successful reclamation to wetland communities are (1) site engineering that provides appropriate chemical and hydrological conditions for wetland plants, (2) selection of foundation species that can tolerate the initial conditions present from the engineered design, (3) successful species establishment and consequent community development of the introduced species, and (4) interactions between a suite of species that provide the structural and functional framework for the future ecosystem (Vitt and Bhatti 2012). However, as conditions evolve during early site development, species tolerances may not be appropriate for the developing site. This is especially true of sites placed on former open-pit mines that have the potential to have changing chemical and hydrological conditions.

In this study, we used a variable and increasing sodium regime set around water chemistry resembling that at Sandhill Wetland and similar to many natural wetlands of the region. Our primary objective was to determine the responses of Carex aquatilis to 
increasing $\mathrm{Na}^{+}$concentrations using a set of structural (biomass, chlorophyll, plant tissue concentrations) and functional (photosynthesis, stomatal conductance, transpiration) attributes. We formulated three questions centered around responses of Carex aquatilis: (1) is there a threshold response of performance to increasing sodium, (2) if so, does it occur in the range of sodium that is present at current reclamation programs, and (3) is Carex aquatilis resistant to high concentrations of sodium?

\section{Materials and methods}

Study site

The 52 ha Sandhill Watershed was constructed on infill of a formerly mined out open pit located on Syncrude Canada Ltd. Oil sands lease at $57.040{ }^{\circ} \mathrm{N}$; $111.596{ }^{\circ} \mathrm{W}$ at $310 \mathrm{~m}$ elevation (Wytrykush et al. 2012). The 60-100 m deep open pit was infilled with composite tailings and pure sand tailings between 1999 and 2008. Ten meters of sand were placed mechanically and form the present-day topography of the watershed. Site construction of the 17 ha central wetland was completed by adding a $0.5 \mathrm{~m}$ of clay sediments designed to reduce hydraulic conductivity and covered by $0.5-1.0 \mathrm{~m}$ of salvaged fresh peat obtained from a nearby peatland with a variety of peatland site-types. The wetland was seeded in winter 2011 with a seed mix composed largely of Carex aquatilis (Vitt et al. 2016). Water was introduced to the wetland in late summer 2012. Currently, the wetland is completely vegetated. Three years after wet-up, Vitt et al. (2016) recognized three plant species assemblages, arranged as zones across a wetness gradient; Zone 1: Typha latifolia-dominated community; Zone 2: Carex aquatilis-dominated community; Zone 3: Calamagrostis canadensis-dominated community, (a Zone 4 was also present, however, comprised of a small number of survey plots). The Zone 2 area contained water table position and plant species assemblages most representative of moderate-rich fens.

In 2019, mean sodium concentrations measured from the water in the top $0-20 \mathrm{~cm}$ of the substrate across Sandhill wetland were $578 \mathrm{mg} \mathrm{L}^{-1}$ in early season to $431 \mathrm{mg} \mathrm{L}^{-1}$ in late season $(n=28)$-a 1.3fold difference between spring and fall. Additionally, mean seasonal variation in $\mathrm{Na}^{+}$varied 1.7 -fold for those areas with highest $\mathrm{Na}^{+}$concentrations (July $971 \mathrm{mg} \mathrm{L}^{-1}$ to September $-571 \mathrm{mg} \mathrm{L}^{-1}, n=09$, ANOVA $\mathrm{p}=0.0001$ ). Sodium concentrations have also increased 1.3 times over the past four years averaging $389( \pm 21.7 \mathrm{SE}) \mathrm{mg} \mathrm{L}^{-1}$ in 2016,489 $( \pm 20.4 \mathrm{SE}) \mathrm{mg} \mathrm{L}^{-1}$ in 2017 , and $573( \pm 22.8 \mathrm{SE}) \mathrm{mg}$ $\mathrm{L}^{-1}$ in 2018 and 513( \pm 17.6 SE ) in 2019. In 2019, sodium concentrations at Sandhill Wetland were spatially quite variable, ranging from $70 \mathrm{mg} \mathrm{L}^{-1}$ to as high as 1,646 $\mathrm{mg} \mathrm{L}^{-1}$ (Vitt et al. 2020). In 2019, photosynthetic rates of $C$. aquatilis growing in areas with high sodium did not differ from plants from soils with low sodium. Net primary production of the species compared well with those from natural sites (Vitt et al. 2020).

\section{Experimental design}

To determine responses of Carex aquatilis to levels of sodium that occur presently or are expected to occur at Sandhill Wetland and other reclamation sites in the future, we conducted a greenhouse experiment from December 13, 2018 to April 3, 2019 (112 days) using germinated $C$. aquatilis seeds collected from Sandhill Wetland. We exposed fully grown plants of $C$. aquatilis to solutions initially containing one of six sodium concentrations: 5, 75, 150, 300, 600, and $1200 \mathrm{mg} \mathrm{L}^{-1} \mathrm{Na}^{+}$. The $5 \mathrm{mg} \mathrm{L}^{-1} \mathrm{Na}^{+}$was used as a control, matching natural rich fen waters (Vitt and Chee 1990).

Carex aquatilis seeds were collected in July 2018 at SHW from six locations with differing levels of sodium, ranging from 0.56 to $5.99 \mathrm{mg} \mathrm{g}^{-1}$ of extracted soil sodium. From dried soil samples, sodium was extracted using a 1:10 ratio of soil to $0.5 \mathrm{~m}$ ammonium acetate $+0.02 \mathrm{~m}$ EDTA, shaken for $16 \mathrm{~h}$ at $200 \mathrm{rpm}$, and filtered through Whatman 1 filter paper, then Whatman 40 filter paper, and lastly $0.22 \mu \mathrm{m}$ filter paper. The filtered sample was then acidified and analyzed through atomic absorption spectroscopy for $\mathrm{Na}^{+}$concentration (AAS spectroscopy model Varian SpectrAA 220 FS). Seeds were wet stratified at $2{ }^{\circ} \mathrm{C}$ on moist paper towels enclosed in plastic bags for 30 days and germinated on moist peat at $20{ }^{\circ} \mathrm{C}$. Seedlings $(2-4 \mathrm{~cm}$ high) were transplanted to $10 \mathrm{~cm}$ square pots with a mixture of $2 / 3$ perlite $-1 / 3$ vermiculite. To maintain soil moisture, each pot was placed in individual $18.4 \mathrm{~cm}$ round 
polypropylene containers that were consistently filled to $400 \mathrm{~mL}$ of distilled water containing Jack's Professional ${ }^{\circledR} \quad$ Water-Soluble Fertilizer (20-3-19 Petunia Feed PlusMg, Allentown, PA;140.3125 ppm $\mathrm{N})$. Plants were left to adjust to their transplant for one month prior to the start of the experiment.

The experiment was performed in the Southern Illinois University Carbondale $\left(\begin{array}{llll}37^{\circ} & 42^{\prime} & 51.9^{\prime \prime} & \mathrm{N}\end{array}\right.$ $89^{\circ} 13^{\prime} 21.7^{\prime \prime} \mathrm{W}$ ) phytotron facility with natural, ambient sunlight and ambient daytime temperatures ranging from 23 to $36{ }^{\circ} \mathrm{C}$ in full sunlight Seventy-two C. aquatilis plants were randomly assigned to one of six sodium treatments each with 12 replicates. Plants were randomly rearranged within the phytotron every 2 weeks. In order to emulate natural seasonal variation at Sandhill Wetland, during each two-week period, consistent water levels were maintained in each container by replacing evaporated water with that from the original stock solutions and at 2-week intervals water was completely replaced in each container. Stock water solutions were prepared for each sodium treatment and contained $7 \mathrm{mg} \mathrm{L}^{-1}$ magnesium, $4 \mathrm{mg} \mathrm{L}^{-1}$ potassium, and $10 \mathrm{mg} \mathrm{L}^{-1}$ calcium to mimic natural fen water conditions (Vitt and Chee 1990). Cations were added to the stock solutions using magnesium sulfate $\left(\mathrm{MgSO}_{4}\right)$, potassium bicarbonate $\left(\mathrm{KHCO}_{3}\right)$, calcium oxide $(\mathrm{CaO})$, and sodium sulfate $\left(\mathrm{Na}_{2} \mathrm{SO}_{4}\right)$ as well as $1 / 8$ teaspoon of the 20-3-19 fertilizer (140.313 ppm N). Due to calcium oxide's water-insoluble nature, we added hydrochloric acid and MES buffer to the $\mathrm{CaO}$ solution in order to bring $\mathrm{pH}$ of the stock solution to neutral (average: $7.38 \pm 0.03 \mathrm{SE}$ ). We added the sodium to the treatment solutions using sulfate as the anion owing to its the dominance at Sandhill Wetland (Hartsock et al. 2019). Water samples from the round polypropylene containers were collected every two weeks, filtered, acidified, and concentration determined through AAS for $\mathrm{Na}^{+}, \mathrm{K}^{+}, \mathrm{Mg}^{2+}$, and $\mathrm{Ca}^{2+}$. Water samples were also analyzed for electrical conductivity (EC) and $\mathrm{pH}$.

For each $C$. aquatilis plant within each treatment, we quantified: (1) longest leaf length of original plant plus longest leaf of all ramets, (2) chlorophyll content, (3) stomatal conductance (defined as overall water loss of the leaf, determined using transpiration rate and leaf surface temperature), (4) transpiration rate (defined as rate at which water vapor accumulates on a leaf over time), (5) photosynthesis rate (defined as rate at which a known area of leaf assimilates $\mathrm{CO}_{2}$ over time), (6) dry aboveground and belowground biomass, and (7) sodium tissue concentrations (aboveground and belowground). Chlorophyll content was determined with a Minolta SPAD 502 chlorophyll meter (Konica Minolta Sensing, Inc., Osaka) every 2 weeks. A CI340 handheld photosynthesis system (CID BioScience, Inc., Camas, WA) was used at 46, 82, and 104 days post-start date to quantify stomatal conductance, transpiration rate, and photosynthesis rate, with three measurements taken for each plant at each of the three time periods. After the breakdown of the experiment, plants were rinsed with DI water and dried at $60{ }^{\circ} \mathrm{C}$ for at least $72 \mathrm{~h}$ to quantify aboveground and belowground biomass. Sodium uptake levels in C. aquatilis roots and shoots were determined using a plant sodium extraction protocol described by Iseki et al. (2017). Roots and shoots were air dried, then ground, and 15-25 mg of sample was weighed. Samples were collected in 2-mL tubes and $500 \mu \mathrm{l}$ of DI water and dry metal beads were added before shaking samples for $2 \mathrm{~h}$. at $200 \mathrm{rpm}$. Samples were centrifuged for $5 \mathrm{~min}$ and $200 \mu \mathrm{l}$ of the supernatant was measured using a $\mathrm{Na}^{+}$ion meter (Horiba).

\section{Statistical analyses}

We characterized the responses to sodium concentrations using analysis of variance. For analysis, the six $\mathrm{Na}^{+}$treatment concentrations were $14 \mathrm{mg} \mathrm{L}^{-1}$, $108 \mathrm{mg} \mathrm{L}{ }^{-1}, 274 \mathrm{mg} \mathrm{L}^{-1}$, $522 \mathrm{mg} \mathrm{L}^{-1}, 1079 \mathrm{mg}$ $\mathrm{L}^{-1}$, and $2354 \mathrm{mg} \mathrm{L}^{-1}$, derived as the mean values at the start and end of each 2-week watering regime. All statistical analyses were performed in SigmaPlot (2008). Outliers were removed from physiological data sets if one of the three measurements was irregular using the Quartile method (Benhadi-Marín 2018). Leaf length (longest leaf length of original plant and longest leaf of any ramets at the end of the experiment), aboveground and belowground biomass, and sodium tissue concentrations were tested against sodium treatment levels using a one-way analysis of variance (ANOVA) and Tukey's pairwise post-hoc comparisons when data passed the Shapiro-Wilks test for normality $(\mathrm{p}<0.05$ failure and visual inspection of residuals). If tests for normality and/or equal variance failed, data were square-root transformed or $\log$ transformed. If neither transformation improved normality or equal variance, the untransformed data 
were analyzed using Kruskal-Wallis one way analysis of variance on ranks followed by Dunn's pairwise post-hoc comparison.

\section{Results}

\section{Water chemistry}

Electrical conductivities within each two-week period increased between 1.3 and 2.2 times (Supplementary Table 1). This increase was manifested in sodium concentrations increasing between 2.1 and 3.2 times, calcium concentrations increasing by 1.7-2.3 times, magnesium $4.2-14.8$ times, and potassium by $2.8-4.4$ times. Mean concentrations for the two highest $\mathrm{Na}^{+}$ treatments during the 2-week intervals were $1100 \mathrm{mg}$ $\mathrm{L}^{-1}$, similar to the higher values where $C$. aquatilis currently is abundant at Sandhill Wetland and $2400 \mathrm{mg} \mathrm{L}^{-1}$, similar to those from sodic fens in the area (Hartsock et al. 2019). Seasonal variation in sodium concentrations at Sandhill Wetland in 2019 for areas with high sodium varied 1.70-fold, while when all areas are considered together, seasonal variation was somewhat less (1.34-fold).
Biomass (Table 1)

Aboveground biomass (Fig. 1a) ranged from 1.94 to $2.38 \mathrm{~g}$ with only slight changes over the 14 to $1079 \mathrm{mg} \mathrm{L}^{-1}$ treatments. Likewise, belowground biomass (Fig. 1b) ranged from 1.88 to $2.51 \mathrm{~g}$ for these five treatments with only small decreases. Comparatively, both aboveground (1.30 g) and belowground biomass ( $0.84 \mathrm{~g})$ were significantly less in the $2354 \mathrm{mg} \mathrm{L}^{-1}$ treatment. The ratio of aboveground to belowground biomass decreased from 1.06 to 0.65 , with 1079 and $2354 \mathrm{mg} \mathrm{L}^{-1}$ treatments different from the $14-522 \mathrm{mg} \mathrm{L}^{-1}$ treatments (Fig. 1c). This effect of increasing sodium was more pronounced in belowground biomass compared to aboveground biomass, with aboveground biomass decreasing $45 \%$ between the end points of treatments, while belowground biomass decreased $68 \%$. Over the spectrum of treatments, there was a gradual decline in aboveground/belowground biomass ratios, with the ratio of aboveground to belowground biomass decreasing $38 \%$ overall.

Table 1 Mean $( \pm \mathrm{SE})$ for plant responses over the six treatments. Treatment are $\mathrm{mg} \mathrm{L}^{-1}$ sodium

\begin{tabular}{|c|c|c|c|c|c|c|}
\hline Treatment & 14 & 108 & 275 & 522 & 1079 & 2354 \\
\hline $\begin{array}{r}\text { Aboveground } \\
\text { biomass }(\mathrm{g})\end{array}$ & $2.38 \pm 0.14$ & $1.94 \pm 0.07$ & $2.37 \pm 0.08$ & $2.19 \pm 0.09$ & $2.27 \pm 0.12$ & $1.30 \pm 0.08$ \\
\hline $\begin{array}{r}\text { Belowground } \\
\text { biomass }(\mathrm{g})\end{array}$ & $2.51 \pm 0.19$ & $2.34 \pm 0.15$ & $2.34 \pm 0.18$ & $2.00 \pm 0.19$ & $1.88 \pm 0.10$ & $0.84 \pm 0.09$ \\
\hline $\begin{array}{l}\text { Below:above-ground } \\
\text { biomass ratio }\end{array}$ & $1.06 \pm 0.05$ & $1.22 \pm 0.08$ & $1.01 \pm 0.09$ & $0.91 \pm 0.08$ & $0.83 \pm 0.02$ & $0.65 \pm 0.06$ \\
\hline Longest Leaf $(\mathrm{cm})$ & $330.63 \pm 19.07$ & $297.15 \pm 12.15$ & $342.27 \pm 20.40$ & $308.68 \pm 21.46$ & $313.20 \pm 18.89$ & $183.09 \pm 12.61$ \\
\hline $\begin{array}{l}\text { Photosynthesis }(\mu \mathrm{mol} \\
\left.\mathrm{m}^{-2} \mathrm{~s}^{-1}\right)\end{array}$ & $4.93 \pm 0.56$ & $5.58 \pm 0.56$ & $5.96 \pm 0.30$ & $5.59 \pm 0.63$ & $4.73 \pm 0.39$ & $2.73 \pm 0.47$ \\
\hline $\begin{array}{l}\text { Transpiration (mmol } \\
\left.\mathrm{m}^{-2} \mathrm{~s}^{-1}\right)\end{array}$ & $1.36 \pm 0.12$ & $1.44 \pm 0.21$ & $1.20 \pm 0.15$ & $1.62 \pm 0.16$ & $1.14 \pm 0.07$ & $0.71 \pm 0.06$ \\
\hline $\begin{array}{l}\text { Stomatal } \\
\text { Conductance } \\
\left(\mathrm{mmol} \mathrm{m} \mathrm{m}^{-2} \mathrm{~s}^{-1}\right)\end{array}$ & $43.03 \pm 3.69$ & $35.96 \pm 5.31$ & $38.18 \pm 4.08$ & $42.87 \pm 4.66$ & $30.91 \pm 1.94$ & $19.47 \pm 1.65$ \\
\hline $\begin{array}{l}\text { Na Aboveground } \\
\text { tissue }\left(\mathrm{mg} \mathrm{g}^{-1}\right)\end{array}$ & $0.86 \pm 0.03$ & $2.16 \pm 0.19$ & $2.34 \pm 0.12$ & $2.37 \pm 0.14$ & $2.81 \pm 0.14$ & $3.60 \pm 0.19$ \\
\hline $\begin{array}{l}\text { Na belowground } \\
\text { tissue }\left(\mathrm{mg} \mathrm{g}^{-1}\right)\end{array}$ & $1.48 \pm 0.10$ & $4.11 \pm 0.29$ & $6.08 \pm 0.30$ & $7.29 \pm 0.33$ & $8.51 \pm 0.42$ & $9.49 \pm 0.38$ \\
\hline $\begin{array}{l}\text { Na below:above- } \\
\text { ground tissue ratio }\end{array}$ & $1.75 \pm 0.14$ & $2.07 \pm 0.24$ & $2.68 \pm 0.21$ & $3.14 \pm 0.15$ & $3.06 \pm 0.10$ & $2.73 \pm 0.20$ \\
\hline
\end{tabular}


(a)

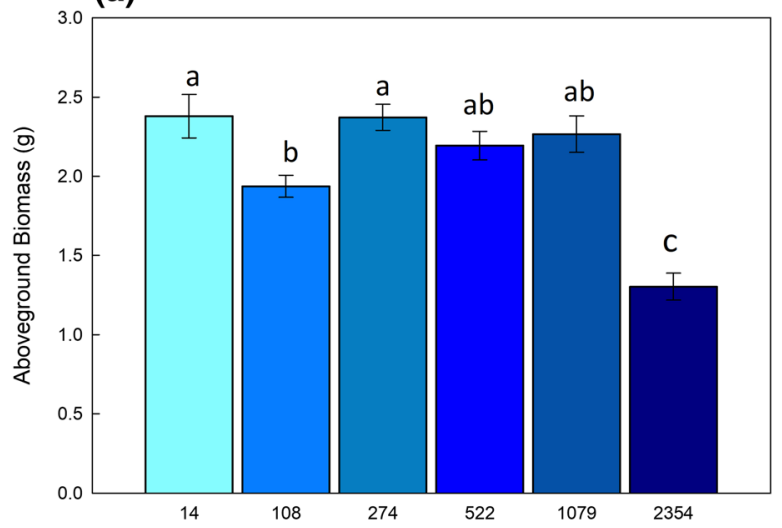

(c)

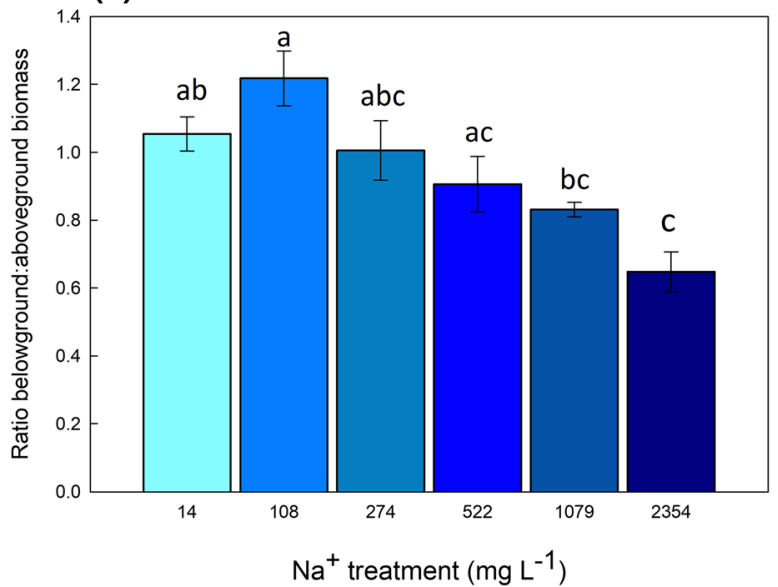

Fig. 1 Responses (as mean ( $\pm \mathrm{SE}$ ) of Carex aquatilis to six concentrations of sodium. a Aboveground biomass $(\mathrm{F}=17.26$, $\mathrm{p}<0.001)$. b Belowground biomass $(\mathrm{F}=15.41, \mathrm{p}<0.001)$. c Ratio of belowground biomass to aboveground biomass $(H=28.93, p<0.001)$. d Longest leaf length $(F=10.43$,

\section{Longest leaf length (Table 1)}

Longest leaf lengths for plants in the $14 \mathrm{mg} \mathrm{L}^{-1}$ treatment averaged $330.63 \mathrm{~cm}( \pm 19.07 \mathrm{SE})$, decreasing to $183.09 \mathrm{~cm}( \pm 12.61 \mathrm{SE})$ for the highest $\mathrm{Na}^{+}$ treatment. Over the six treatments the longest leaf lengths decreased $45 \%$ (Fig. 1d) with the treatment of $2354 \mathrm{mg} \mathrm{\textrm {L } ^ { - 1 }}$ different from the remaining five treatments.

\section{Chlorophyll content}

Chlorophyll content did not differ among the six treatments $(\mathrm{H}=2.85, \mathrm{p}=0.723)$. (b)

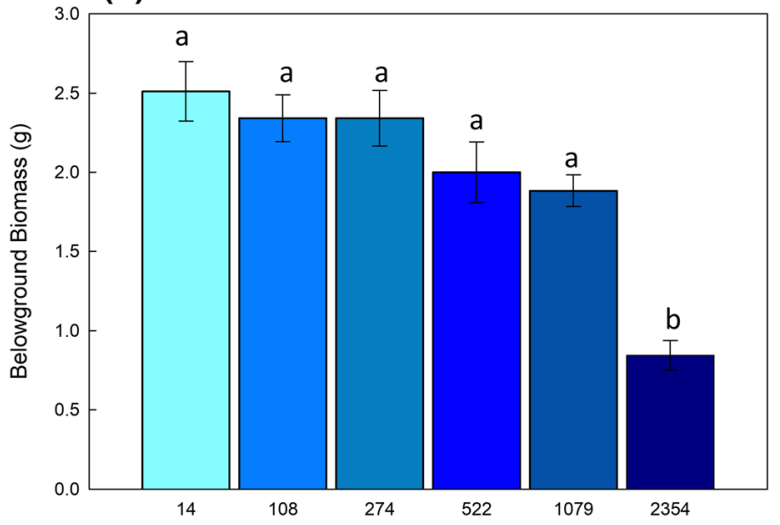

(d)

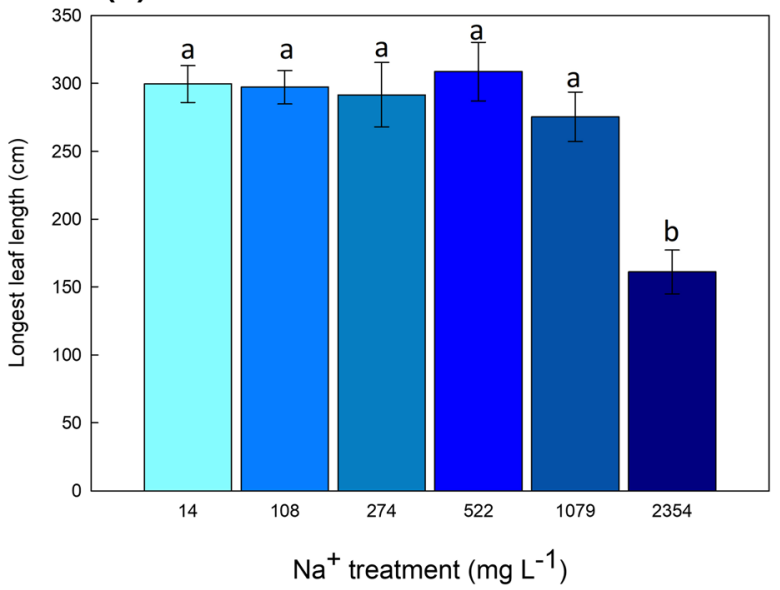

$\mathrm{p}<0.001)$. Different letters indicate significantly different values between treatments ( $\mathrm{F}=$ Tukey's pairwise post-hoc test at $\mathrm{p}=/<0.05$ or $\mathrm{H}=$ Dunn's pairwise post-hoc comparison at $\mathrm{p}=0.05)$. All data taken at end of experiment

Photosynthetic rate (Table 1)

Collectively, photosynthetic rates for $C$. aquatilis were higher, on average, on day 46 than on days 82 (1.4 times higher) and 104 (1.3 times higher). On day 104 (at the end of the experiment), there was a decline in photosynthetic rate, decreasing by $41 \%$ among the six treatments, but particularly noticeable in the $2354 \mathrm{mg} \mathrm{L}^{-1}$ treatment compared to the lower treatments (Fig. 2a).

Transpiration rate (Table 1)

The mean transpiration rate decreased $47 \%$ from $1.35 \mathrm{mmol} \mathrm{m}{ }^{-2} \mathrm{~s}^{-1}( \pm 0.12 \mathrm{SE})$ in the $14 \mathrm{mg} \mathrm{L}^{-1}$ 
(a)

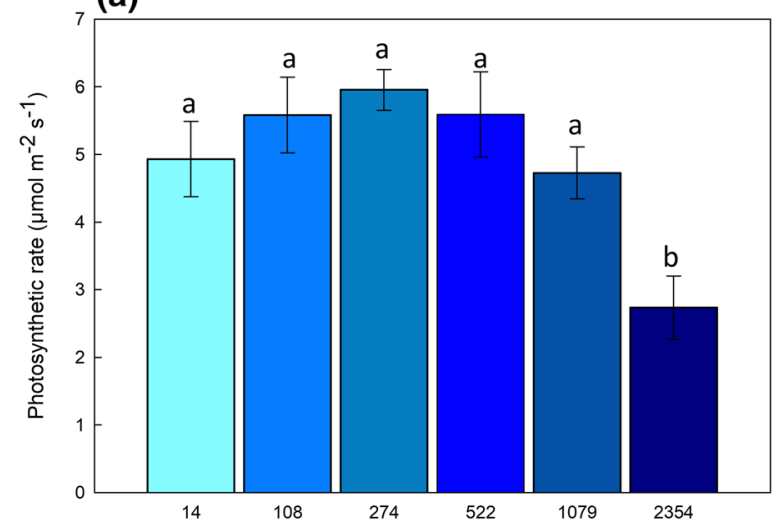

(c)

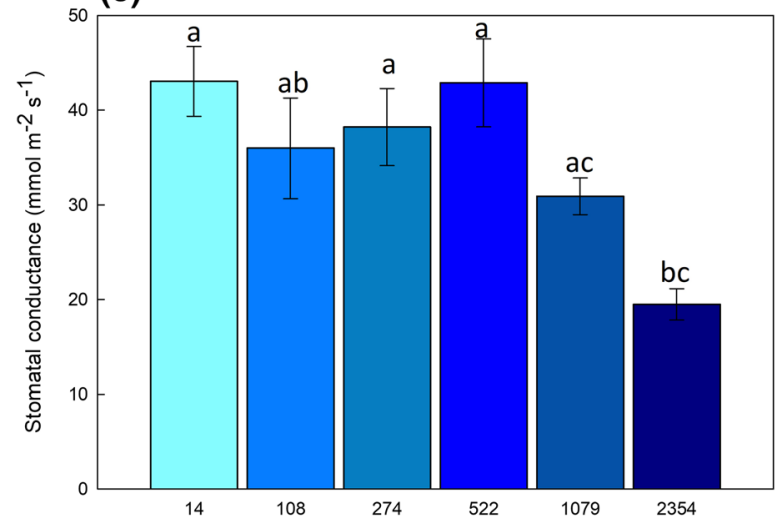

(e)

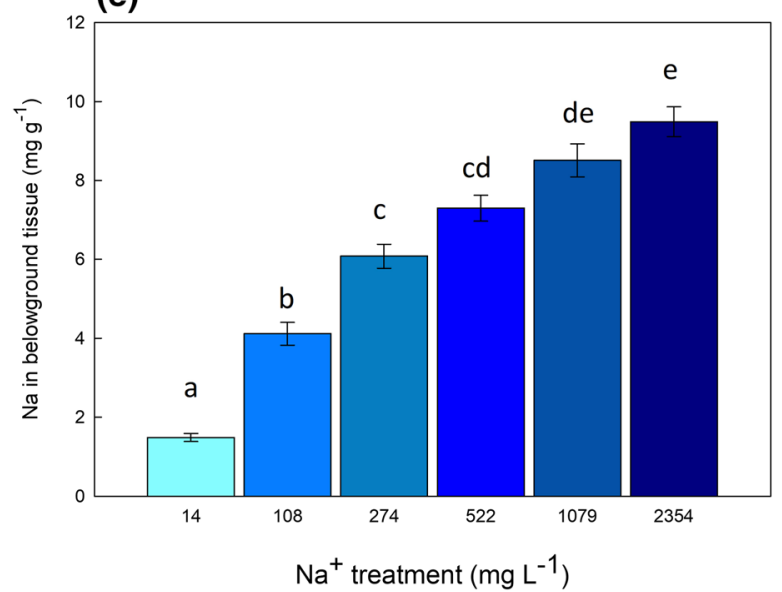

Fig. 2 Responses (as mean ( $\pm \mathrm{SE}$ ) of Carex aquatilis to six concentrations of sodium. a Photosynthetic rate $(\mathrm{F}=6.08$, $\mathrm{p}<0.001)$. b Transpiration rate $(\mathrm{H}=22.61, \mathrm{p}<0.001)$. c Stomatal conductance $(\mathrm{H}=24.08, \mathrm{p}<0.001)$. d Above round tissue concentration of sodium $(\mathrm{F}=52.09, \mathrm{p}<0.001)$. e Belowground tissue concentration of sodium $(\mathrm{F}=179.38$, (b)

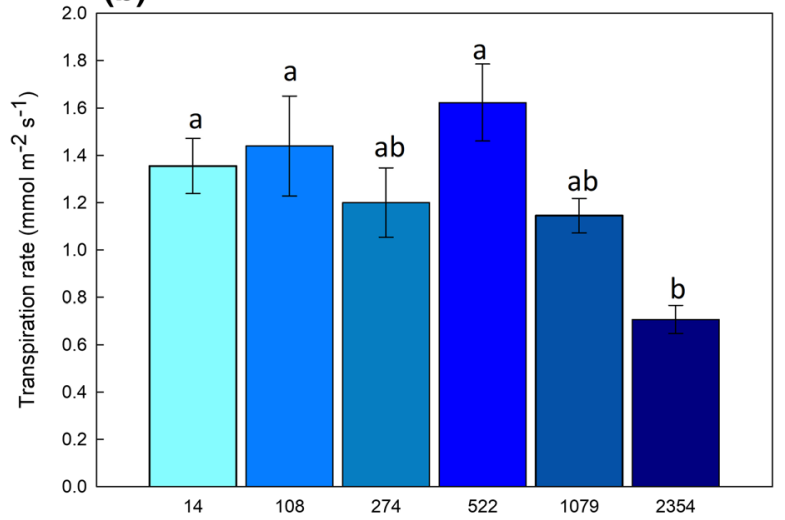

(d)

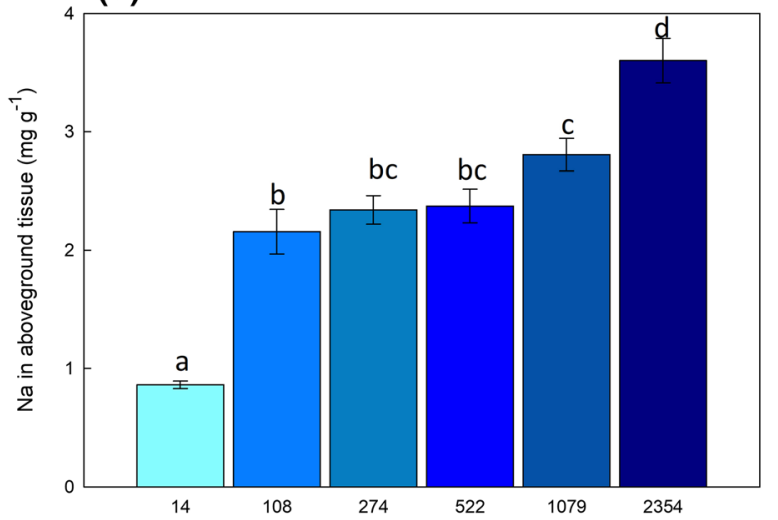

(f)

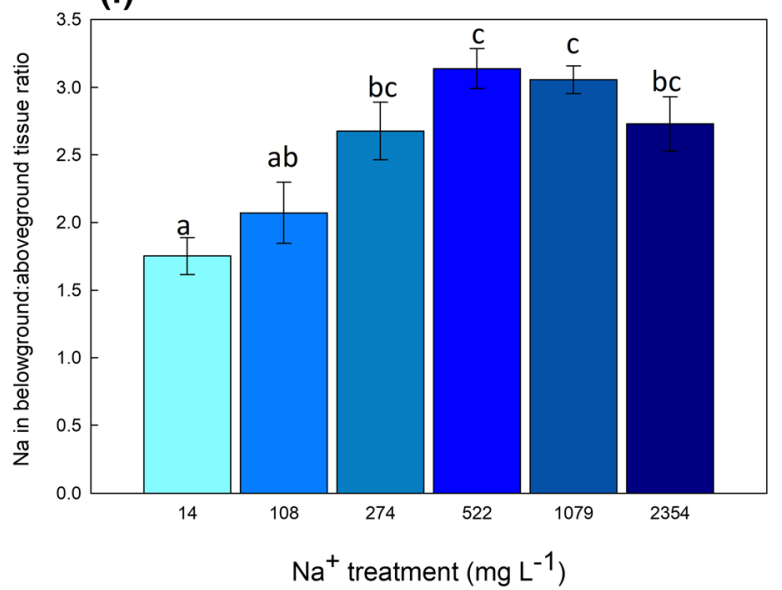

$\mathrm{p}=0.001$ ). f Ratio of belowground to aboveground tissue concentration of sodium $(\mathrm{F}=10.24, \mathrm{p}<0.001)$. Different letters indicate significantly different values between treatments ( $\mathrm{F}=$ Tukey's pairwise post-hoc test at $\mathrm{p}=<0.05$ or $\mathrm{H}=$ Dunn's pairwise post-hoc comparison at $\mathrm{p}=0.05$ ). All data taken at end of experiment 
treatment to $0.71 \mathrm{mmol} \mathrm{m}^{-2} \mathrm{~s}^{-1}( \pm 0.06 \mathrm{SE})$ in the $2354 \mathrm{mg} \mathrm{L}^{-1}$ treatment (Fig. 2b).

Stomatal conductance (Table 1)

Stomatal conductance decreased substantially from a mean of $43 \mathrm{mmol} \mathrm{m}^{-2} \mathrm{~s}^{-1}( \pm 3.69 \mathrm{SE})$ in the control to $19 \mathrm{mmol} \mathrm{m}{ }^{-2} \mathrm{~s}^{-1}( \pm 1.65 \mathrm{SE})$ at the highest $\mathrm{Na}^{+}$ treatment, a decrease of $55 \%$ (Fig. 2c). Stomatal conductance was correlated to transpiration rate $\left(\mathrm{p}=1.047 \mathrm{E}-052, \mathrm{R}^{2}=0.908\right)$ and photosynthesis rate $\left(\mathrm{p}=2.106 \mathrm{E}-018, \quad \mathrm{R}^{2}=0.566\right.$-Pearson Product Moment Correlation).

Sodium concentrations in above- and belowground biomass (Table 1)

The concentration of sodium present in plant tissues increased in both aboveground (Fig. 2d) and belowground (Fig. 2e) biomass of Carex aquatilis. In aboveground tissues, sodium increased from 0.9 to $3.6 \mathrm{mg} \mathrm{g}^{-1}$, whereas in belowground tissues the increase was more dramatic, from 1.5 to $9.5 \mathrm{mg}$ $\mathrm{g}^{-1}$. This large increase in sodium in belowground tissues contributed to the ratio of sodium (belowground/aboveground) increasing from 1.75 to 3.14 , 3.06, and 2.73 in the highest treatments. (Fig. 2f). The total amount of sodium in belowground biomass increased two-fold from lowest to highest treatment (4.00 mg to $7.97 \mathrm{mg}$; belowground biomass mean $\mathrm{x}$ $\mathrm{Na}$ concentration mean) compared to total sodium in aboveground tissue that increased from 2.04 to $4.68 \mathrm{mg}$. Sodium concentrations in the belowground biomass increase in a curvi-linear pattern as belowground biomass decreases (regression $\mathrm{r}^{2}=0.430$, Supplmentary Fig. 1).

\section{Discussion}

Sandhill Wetland was designed to serve as a predictor of how wetlands on infilled open pit mines could be engineered and how the water chemistry and plant communities would develop as the site changed in its first decade or so (Wytrykush et al. 2012). After three years, plant communities were largely influenced by water levels (Vitt et al. 2016); however, increasing cation concentrations, especially sodium, have become more important over the past several years (years 5-8; Biagi et al. 2019).

We addressed our first two questions of whether there is a threshold response of $C$. aquatilis to increasing concentrations of sodium and if so, is it in the range of current site conditions through a set of six treatments ranging from 14 to $2354 \mathrm{mg} \mathrm{L}^{-1}$ sodium. All components of biomass and rates of photosynthesis, stomatal conductance, and transpiration showed significant decreases in performance above $1079 \mathrm{mg}$ $\mathrm{L}^{-1}$. Biomass components decreased between 45 and $68 \%$, with belowground biomass more strongly affected by higher concentrations of sodium. The ratio of below- to aboveground biomass increased from about one in the treatment with lowest sodium concentration to more than 2.5 in higher treatments. Comparably, functional attributes of photosynthesis, transpiration, and stomatal conductance decreased between 41 and $55 \%$. The nearly identical slopes and correlative decrease $\left(\mathrm{R}^{2}=0.566\right)$ in stomatal conductance and photosynthetic rates provide a clear indication that the latter is strongly affected by the former. Likewise, the rate of transpiration is highly correlated with stomatal conductance $\left(\mathrm{R}^{2}=0.908\right)$. These results demonstrate that increased sodium concentrations affect photosynthetic rates by reduction in stomatal conductance and consequent restriction of availability of $\mathrm{CO}_{2}$.

In 2019, sodium concentrations were variable over the Sandhill Wetland. Overall mean values were near $500 \mathrm{mg} \mathrm{L}^{-1}$; however, some sites had values as high as $1646 \mathrm{mg} \mathrm{L}^{-1}$. These high sodium concentrations are unlike those of natural rich fens of the region (Vitt and Chee 1990) and resemble values found in brackish marshes (Hartsock 2020). Carex aquatilis is abundant in fens and marshes of Alberta, but does not occur in sodic fens with sodium concentration above $1900 \mathrm{mg}$ $\mathrm{L}^{-1}$ (Hartsock 2020). Performance of $C$. aquatilis at $1079 \mathrm{mg} \mathrm{L}^{-1}$ is similar to that at lower concentrations and also similar to conditions presently at Sandhill Wetland; however, the strong decrease in performance at $2354 \mathrm{mg} \mathrm{L}^{-1}$ suggests a threshold that may be in the realm of conditions at reclamation sites in the future. Currently, it is not known whether cation concentrations will continue to rise at Sandhill Wetland, but if they do, they could reach a point affecting the growth and occurrences of $C$. aquatilis, the dominant species on the wetland at the present time. 
Our third question explored the possible mechanism of how $C$. aquatilis can tolerate such a broad range of sodium concentrations. Many non-halophytes maintain salt tolerance by exclusion of sodium by the roots from the shoots (Greenway and Munns 1980; Munns and Tester 2008) and this appears to be the case for $C$. aquatilis. Belowground/aboveground ratios of sodium tissue concentrations increased dramatically (from 1:75 to around or just below 3.0 for the higher concentrations). Aboveground ratios increased some 4-fold while belowground ratios increased just over six times. These increases in belowground to aboveground tissue concentrations as sodium treatments increased may be, at least in part, the reason for the high tolerance of $C$. aquatilis to increasing sodium concentrations. Additionally, the total quantity of sodium in the aboveground tissue increased from approximately $2.0 \mathrm{mg}$ to $4.7 \mathrm{mg}$ over the course of treatments, compared to much higher quantities in the belowground tissue, varying from $4.0 \mathrm{mg}$ in the lowest treatment to almost $8.0 \mathrm{mg}$ in the highest, again suggesting that the belowground biomass is retaining sodium. However, at the higher sodium treatment concentrations the ratios of sodium tissue concentrations (belowground/aboveground) level off and decrease at the highest treatment suggesting saturation of the belowground biomass.

\section{Conclusions}

Carex aquatilis is highly tolerant of sodium concentrations up to $1079 \mathrm{mg} \mathrm{L}^{-1}$. At concentrations above this level, performance is reduced by about $50 \%$. Both structural and functional attributes are affected in a similar fashion. Reduction in photosynthesis is strongly correlated with reduced stomatal conductance and lower transpiration. At the higher concentrations of sodium, belowground tissue concentrations of sodium are considerably higher than those of aboveground tissues and increase along with increases in sodium, suggesting the sodium is being excluded from the aboveground tissue by the belowground tissues. Sandhill Wetland currently exhibits sodium concentrations that have consistently increased over the past 4 years and are as high as $1646 \mathrm{mg} \mathrm{L}^{-1}$ in some sites. These decreases in performance in our greenhouse trials occur at sodium concentrations that are just above those present at Sandhill Wetland and careful assessment of sodium concentrations in the near future needs to be continued.

Acknowledgements We would like to thank Southern Illinois University Carbondale and the SIUC School of Biological Sciences for providing research space. We thank Ava Alford, Jeremy Hartsock, Kemar Jones, Derek Tollette, and Brian Widmer for field/lab assistance and especially Syncrude Canada, Ltd. for funding this research. We are grateful to Carla Wytrykush and to Jessica Clark (both Syncrude Canada) for support while at Syncrude. Comments from two reviewers greatly improved the manuscript for which we are grateful.

Author contributions DHV conceived of the design and wrote the manuscript, LCG produced the statistical outputs and graphics, $\mathrm{MH}$ assisted in the design and set up of the experiment; SPK and MH carried out the greenhouse experiment.

Funding Syncrude Canada Ltd funded this research.

\section{Compliance with ethical standards}

Conflict of interest The authors have no conflicts of interest.

Open Access This article is licensed under a Creative Commons Attribution 4.0 International License, which permits use, sharing, adaptation, distribution and reproduction in any medium or format, as long as you give appropriate credit to the original author(s) and the source, provide a link to the Creative Commons licence, and indicate if changes were made. The images or other third party material in this article are included in the article's Creative Commons licence, unless indicated otherwise in a credit line to the material. If material is not included in the article's Creative Commons licence and your intended use is not permitted by statutory regulation or exceeds the permitted use, you will need to obtain permission directly from the copyright holder. To view a copy of this licence, visit http://creativecommons.org/licenses/by/4.0/.

\section{References}

Adams JJ, Rostron BJ, Mendoza CA (2004) Coupled fluid flow, heat and mass transport, and erosion in the Alberta basin: implications for the origin of the Athabasca oil sands. Can J Earth Sci 41:1077-1095

Benhadi-Marín J (2018) A conceptual framework to deal with outliers in ecology. Biodivers Conserv 27(12):3295-3300

Bernard JM, Gorham E (1978) Life history aspects of primary production in sedge wetlands. In: Good RE, Whigham DF, Simpson RL (eds) Freshwater wetlands; ecological processes and management potential. Academic, New York, pp 39-51

Biagi KM, Oswald CJ, Nichols EM, Carey SK (2019) Increases in salinity following a shift in hydrologic regime in a constructed wetland watershed in a post-mining oil sands 
landscape. Sci Total Environ 653:1445-1457. https://doi. org/10.1016/j.scitotenv.2018.10.341

Bliss LC, Grulke NE (1988) Revegetation in the high Arctic: its role in reclamation of surface disturbance Northern environmental disturbances, vol 14. Boreal Institute of Northern Studies, University of Alberta, Edmonton, pp 43-55

Chapin FS, Chapin MC (1981) Ecotypic differentiation of growth processes in Carex aquatilis along latitudinal and local gradients. Ecology 62:1000-1009

Choo YS, Song SD, Albert R (2001) Effects of salinity on growth and patterns of ions and organic solutes in five sedges (Carex spp.) with different ecological demands. Flora 196:71-80

Gignac LD, Gauthier R, Rochefort L, Bubier J (2004) Distribution and habitat niches of 37 peatland Cyperaceae species across a broad geographic range in Canada. Can J Bot 82:1292-1313

Glaeser LC, Vitt DH, Ebbs S (2016) Responses of the wetland grass, Beckmannia syzigachne, to salinity and soil wetness: consequences for wetland reclamation in the oil sands area of Alberta, Canada. Ecol Eng 86:24-30

Gorham E, Somers ME (1973) Seasonal changes in the standing crop of two montane sedges. Can J Bot 51:1097-1108

Government of Alberta (2015) Oil sands. Reclamation. Government of Alberta. http://oilsands.alberta.ca/ FactSheets.FactSheet-Reclamation-2015.pdf. Accessed 1 Mar 2019

Greenway H, Munns R (1980) Mechanisms of salt tolerance in nonhalophytes. Annu Rev Plant Physiol 31:149-190

Hartsock J (2020) Characterization of key performance measures at reclaimed Sandhill Wetland: implications for achieving wetland reclamation success in the Athabasca oil sands region. Ph.D. Dissertation, Southern Illinois University, Carbondale, IL

Hartsock JA, Bremer E, Vitt DH (2019) Nutrient supply patterns across the Sandhill Fen reclamation watershed and regional reference fens in Alberta, Canada: an ion exchange membrane study. Ecohydrology. https://doi.org/10.1002/eco. 2188

Hultén E (1968) Flora of alaska and neighboring territories. Stanford University Press, Stanford, p 1008

Iseki K, Marubodee R, Ehara H, Tomooka N (2017) A rapid quantification method for tissue $\mathrm{Na}+$ and $\mathrm{K}+$ concentrations in salt-tolerant and susceptible accessions in Vigna vexillata (L.) A. Rich. Plant Prod Sci 20:144-148

Kessler S, Barbour SL, Van Rees KC, Dobchuk BS (2010) Salinization of soil over saline-sodic overburden from the oil sands in Alberta. Can J Soil Sci 90:637-647

Khasa PD, Hambling B, Kernaghan G, Fung M, Ngimbi E (2002) Genetic variability in tolerance of selected boreal woody seedlings. For Ecol Manag 165:257-269

Koropchak S, Vitt DH (2013) Survivorship and growth of Typha latifolia $\mathrm{L}$. across a $\mathrm{NaCl}$ gradient: a greenhouse study. Int $\mathrm{J}$ Min Reclam Environ 27:143-150

Koropchak S, Vitt DH, Bloise R, Wieder RK (2012) Fundamental paradigms, foundation species selection, and early plant responses to peatland initiation on mineral soils. In: Vitt DH, Bhatti J (eds) Restoration and reclamation of boreal ecosystems: attaining sustainable development. Cambridge University Press, Cambridge, pp 76-100
Mollard FP, Roy MC, Frederick K, Foote L (2012) Growth of the dominant macrophyte Carex aquatilis is inhibited in oil sands affected wetlands in Northern Alberta, Canada. Ecol Eng 38:11-19

Montemayor MB, Price JS, Rochefort L, Boudreau S (2008) Temporal variations and spatial patterns in saline and waterlogged peat fields 1 . Survival and growth of salt marsh graminoids. Environ Exp Bot 62:333-342

Munns R, Tester M (2008) Mechanisms of salinity tolerance. Annu Rev Plant Biol 59:651-681

Purdy BG, Macdonald E, Lieffers VJ (2005) Naturally saline boreal communities as models for reclamation of saline oil sand tailings. Restor Ecol 13:667-677

Raab D, Bayley SE (2013) A Carex species-dominated marsh community represents the best short-term target for reclaiming wet meadow habitat following oil sands mining in Alberta, Canada. Ecol Eng 54:97-106. https://doi.org/ 10.1016/jecoleng.2013.01.024

Raine M, Mackenzie L, Gilchrist L (2002) Terrestrial vegetation, wetlands and forest resources baseline report. CNRL Horiz Project Environ Impact Assess Append B 6:012-2220

Renault S, Lait C, Zwiazek JJ, MacKinnon M (1998) Effect of high salinity tailings waters produced from gypsum treatment of oil sands tailings on plants of the boreal forest. Environ Pollut 102:177-178

Renault S, Paton E, Nilsson G, Zwiazek JJ, MacKinnon MD (1999) Responses of boreal plants to high salinity oil sands tailings water. J Environ Qual 28:1957-1962

Rooney RC, Bayley SE, Creed IF, Wilson MJ (2012) The accuracy of land cover-based wetland assessments is influenced by landscape extent. Landsc Ecol 27:1321-1335

SigmaPlot (2008) Version 11. Systat Software, Inc., San Jose

Vessey CJ, Lindsay MB, Barbour SL (2019) Sodium transport and attenuation in soil cover materials for oil sands mine reclamation. Appl Geochem 100:42-54

Trites M, Bayley SE (2009) Vegetation communities in continental boreal wetlands along a salinity gradient: implications for oil sands mining reclamation. Aqua Bot 91:27-39. https://doi.org/10.1016/j.aquabot.2009.01.003

Vitt D, Bhatti J (2012) Incorporating ecological theory into restoration planning. In: Vitt DH, Bhatti J (eds) Restoration and reclamation of boreal ecosystems: attaining sustainable development. Cambridge University Press, Cambridge, pp 3-12

Vitt DH, Chee WL (1990) The relationships of vegetation to surface-water chemistry and peat chemistry in fens of Alberta, Canada. Vegetatio 89:87-106

Vitt DH, Wieder RK, Xu B, Kaskie M, Koropchak S (2011) Peatland establishment on mineral soils: effects of water level, amendments, and species after two growing seasons. Ecol Eng 37:354-363. https://doi.org/10.1016/j.ecoleng. 2010.11.029

Vitt DH, House M, Hartsock JA (2016) Sandhill Fen, an initial trial for wetland species assembly on in-pit substrates: lessons after three years. Botany 94:1015-1025

Vitt DH, House M, Hartsock JA (2020) Final report for the ecology of Sandhill Fen 2016-2019. Syncrude Canada, Ltd., Fort McMurray 
Wieder RK, Vile MA, Scott KD, Albright CM, McMillen KJ, Vitt DH, Fenn ME (2016) Differential effects of high atmospheric $\mathrm{N}$ and $\mathrm{S}$ deposition on bog plant/lichen tissue and porewater chemistry across the Athabasca Oil Sands Region. Environ Sci Technol 50:12630-12640

Wytrykush C, Vitt D, McKenna G, Vassov R (2012) Designing landscapes to support peatland development on soft tailings deposits. In: Vitt D, Bhatti J (eds) Restoration and reclamation of boreal ecosystems: attaining sustainable development. Cambridge University Press, Cambridge, pp 161-178 